\title{
Faktor-Faktor yang Mempengaruhi Lamanya Penyembuhan Luka Perineum pada Ibu Nifas di Ruang Perawatan Rumah Sakit Mitra Manakarra Mamuju
}

\author{
Andi Ernawati Manuntungi ${ }^{1 *}$, Irmayanti ${ }^{2}$, Ratna $^{3}$ \\ 1*. STIKES ST. Fatimah Mamuju, Jl. Soekarno Hatta No. 09., Kota Mamuju, Indonesia, 91511 \\ 2. Akademi Kebidanan Konawe, Jl. DII Panjaitan No. 217, Kabupaten Konawe, Indonesia, 93415 \\ 3. STIKES Nani Hasanuddin Makassar, Jl. P. Kemerdekaan VIII No.24, Kota Makassar, Indonesia, 90245 \\ *e-mail : manuntungi.ernha@gmail.co.id/085396622333
}

(Received : 08-08-2019; Reviewed : 21-08-2019; Accepted : 26-08-2019)

\begin{abstract}
Perineal rupture is a tear that occurs in the perineal area during labor. Perineum plays a role in labor because it is the outside of the pelvic floor. Perineum is located between the vulva and anus, the average length is $4 \mathrm{~cm}$. Objective: To determine the factors that influence the duration of perineal wound healing in postpartum mothers in the treatment room of Mitra Manakarra Hospital, Mamuju, Mamuju Regency. Method: An analytic cross-sectional that was carried out in the care room of Mitra Manakarra Hospital, Mamuju. The sample in this study was the puerperal woman who suffered stitching injuries due to perineal rupture. The population in the study was 36 and the sampling technique used total sampling. Data collection by distributing questionnaires containing questions about the factors that influence the duration of perineal wound healing in postpartum mothers. Results: Based on the Chi-Squared test $\rho$-value 0.878>0.05: there was no relationship between age and duration of perineal wound healing. Fisher's Exact Test analysis results obtained pvalues smaller than the value a $(0.018<0.05)$ means that there is a relationship between nutritional status and the duration of healing of the perineal wound. Chi square analysis test results obtained pvalues greater than the value of a $(0.221<0.05)$ means that there is no relationship between education with the duration of healing of the perineal wound. Conclusion: eating foods high in protein is good during pregnancy until the puerperium like eating high protein foods like cork fish, because foods high in protein can regenerate wounds quickly.
\end{abstract}

Keywords: Perineal Wound, Puerperal Mother

\begin{abstract}
Abstrak
Ruptur perineum adalah robekan yang terjadi di daerah perineum sewaktu persalinan.Perineum berperan dalam persalinan karena merupakan bagian luar dari dasar panggul. Perineum yang terletak antara vulva dan anus, panjangnya rata-rata $4 \mathrm{~cm}$. Tujuan : Mengetahui Faktor-faktor yang mempengaruhi lamanya penyembuhan luka perineum pada ibu nifas di Ruang perawatan Rumah Sakit Mitra Manakarra Mamuju Kabupaten Mamuju. Metode : Analitik dengan pendekatan studi cross sectional yang dilaksanakan di ruang perawatan Rumah Sakit Mitra Manakarra Mamuju. Sampel dalam penelitian ini adalah ibu nifas yang mengalami luka jahitan akibat ruptur perineum. Jumlah populasi dalam penelitian adalah 36 dan teknik penarikan sampel menggunakan total sampling. Pengumpulan data dengan membagikan kuesioner yang berisi pertanyaan tentang faktor - faktor yang mempengaruh lamanya penyembuhan luka perineum pada ibu nifas. Hasil Penelitian : berdasarkan uji ChiSquaredidapatkan $\mathrm{P}$ value $0,878>0,05$ : tidak terdapat hubungan antara usia dengan lama penyembuhan luka perineum. Hasil uji analisis Fisher's Exact Test diperoleh $\rho_{\text {value }}$ lebih kecil dari nilai a $(0,018<0,05)$ artinya terdapat hubungan antara status gizi dengan lama penyembuhan luka perineum. Hasil uji analisis chi square diperoleh $\rho_{\text {value }}$ lebih besar dari nilai a $(0,221<0,05)$ artinya tidak ada hubungan antara pendidkan dengan lama penyembuhan luka perineum. Kesimpulan :makan makanan yang tinggi protein baik selama hamil sampai masa
\end{abstract}


nifas seperti makan makanan yang berprotein tinggi seperti ikan gabus, karena makanan tinggi protein dapat meregenerasi luka dengan cepat.

Kata Kunci : Ibu Nifas, Luka Perineum

\section{Pendahuluan}

Derajat kesehatan suatu Negara ditentukan oleh beberapa indikator, salah satunya adalah Angka Kematian Ibu (AKI). AKI di Indonesia pada periode 1991-2007 mengalami penurunan dari 390 menjadi 228 per 100.000 kelahiran hidup, namun pada Survei Demografi Kesehatan Indonesia (SDKI, 2012) AKI kembali naik menjadi 359 per 100.000 kelahiran hidup (KH). Pada tahun 2015 AKI menunjukkan penurunan yaitu 305 kematian per 100.000 kelahiran hidup. Meskipun mengalami penurunan, namun angka tersebut masih tergolong tinggi (Kemenkes, RI. 2016). Masa nifas adalah masa yang dimulai setelah plasenta keluar dan berakhir ketika alatalat kandungan kembali seperti keadaan semula (sebelum hamil) dan berlangsung kira-kira 6 minggu (Prawirohardjo, 2012).

Masa nifas merupakan masa pemulihan kondisi ibu. Pada masa nifas luka perineum harus mendapat penanganan yang baik sehingga infeksi tidak terjadi karena perawatan perineum yang tidak benar dapat mengakibatkan kondisi perineum yang terkena lokhea dan lembab akan sangat menunjang perkembang biakan bakteri yang dapat menyebabkan timbulnya infeksi pada perineum (Prawirohardjo, 2012). Munculnya infeksi pada perineum dapat merambat pada saluran kandung kencing ataupun pada jalan lahir yang dapat berakibat pada munculnya komplikasi infeksi kandung kencing maupun pada jalan lahir. Penanganan komplikasi yang lambat dapat menyebabkan terjadinya kematian ibu post partum mengingat kondisi ibu masih lemah (Chrisvalen, 2012). Biasanya penyembuhan luka pada robekan perineum ini akan sembuh bervariasi, ada yang sembuh normal dan ada yang mengalami kelambatan dalam penyebuhannya, hal tersebut dapat dipengaruhi oleh beberapa hal diantaranya karakteristik ibu bersalin, status gizi, kondisi perlukaan, perawatanya dan berbagai faktor lainnya. Umur dan status gizi merupakan salah satu faktor yang mempengaruhi lama penyembuhan luka perineum (Rukiyah, dkk. 2012).

Faktor penyebab luka jahitan perineum pada ibu nifas antara lain partus presipitatus yang tidak dikendalikan dan tidak ditolong, pasien tidak mampu berhenti mengejan, partus diselesaikan secara tergesa-gesa dengan dorongan fundus yang berlebih, edema dan kerapuhan pada perineum, vasikositas vulva yang melemah jaringan perineum, arkus pubis sempit dengan pintu bawah panggul yang sempit pula sehingga menekan kepala bayi kearah posterior, dan perluasan episiotomi (Oxorn, 2010). Sedangkan Faktor penyebab janinnya antara lain bayi besar, posisi kepala yang abnormal, kelahiran bokong, ekstraksi forcep yang sukar, dan distosia bahu (Oxorn, 2010).

Penelitian yang dilakukan oleh Darmawati dan Ia Sastra (2012) di Aceh menemukan bahwa infeksi, stress dan istrahat berhubungan dengan lama penyembuhan luka perineum. Begitupula penelitian yang dilakukan oleh Yulia Handayani dan Adri Idiana (2014) di Aceh pengaruh status gizi dan personal hygiene terhadap penyembuhan luka perineum. Sedangkan penelitian yang dilakukan oleh Anita Ri Sukisno (2014) di Mojokerto menemukan bahwa senam nifas mempercepat proses penyembuhan luka perineum.

Terdapat perbedaan yang signifikan antara didalam struktur dan karakteristik kulit sepanjang rentang kehidupan, yang disertai dengan perubahan fisiologi normal berkaitan dengan usia yang terjadi pada sistem tubuh lainnya, yang dapat mempengaruhi predisposisi terhadap cedera dan efisiensi mekanisme penyembuhan luka (Kozier, 2011).

Beberapa dari perbedaan ini dan dampak klinisnya dibahas secara kronologis, dimulai dengan bayi praterm.Masalah-masalah akibat dari barier kulit yang jauh kurang efektif dan kulitnya sangat mudah terkena trauma, akibat stratum korneum yang tipis dan buruk perkembangannya dan karena instabilitas epidermaldermal. Hal tersebut mempunyai implikasi penting terhadap berbagai aspek asuhan keperawatan bagi bayi-bayi praterm :Pemilihan dan penggunaan sabun, serta frekuensi mandi, penggunaan obat-obat topikal, seperti antiseptik, krim steroid, dan krim pelembut, yang mungkin saja diserap secara berlebihan melalui perkutaneus (Kozier, 2011).

Pencegahan nekrosis akibat tekanan, khususnya pada oksiput.Pemilihan metode untuk mengamankan peralatan.Hal tersebut secara khusus penting supaya tidak memasang peralatan pada bayi praterm dengan plester yang mengandung zat adesif kuat, karena kerusakan epidermal yang besar dapat terjadi saat plester dilepaskan.Karena sistem imun yang masih lemah, bayi-bayi praterm sangat rentan terhadap infeksi, termasuk infeksi pangkal umbilikus oleh organisme gram negatif dan infeksi S. Aureus, Candida, dan infeksi yang melibatkan stafilokokus koagulase negatif, yang normalnya hanya merupakan koloni pada kulit (Kozier, 2011).

Kebutuhan kalori dan protein pasien hampir pasti menjadi lebih tinggi daripada orang normal ketika terdapat luka yang besar.Asam amino diperlukan untuk sintesis protein struktural seperti kolagen dan untuk melakukan 
sintesa protein yang berperan didalam respon imun. Pada stadium awal setelah luka yang besar, berbagai sistem endokrin dan sistem saraf mengadakan reaksi terhadap cedera yang kemudian memicu proses proses katabolik yang merusak jaringan tubuhnya sendiri untuk menyediakan bahan-bahan yang diperlukan bagi proses perbaikan yang sifatnya segera (Kozier, 2011).

Penelitian yang dilakukan oleh Darmawati dan Ia Sastra (2012) di Aceh menemukan bahwa infeksi, stress dan istrahat berhubungan dengan lama penyembuhan luka perineum. Begitupula penelitian yang dilakukan oleh Yulia Handayani dan Adri Idiana (2014) di Aceh pengaruh status gizi dan personal hygiene terhadap penyembuhan luka perineum. Sedangkan penelitian yang dilakukan oleh Anita Ri Sukisno (2014) di Mojokerto menemukan bahwa senam nifas mempercepat proses penyembuhan luka perineum.

Berdasarkan studi pendahuluan yang dilakukan di Ruang Perawatan Rumah Sakit Mitra Manakarra Mamuju, menemukan dari Januari-April 2017 jumlah ibu nifas post Sectio caesarea 129 orang danibu nifas post normal 98 orang. Dari 98 ibu post normal terdapat $36 \mathrm{ibu}$ yang mengalami luka perineum dari persalinan normal di ruang Perawatan Rumah Sakit Mitra Manakarra Mamuju.

\section{Metode}

Jenis penelitian yang digunakan analitik dengan pendekatan studi cross Sectional, Teknik pengambilan sampel dengan total sampling. Sedangkan Kriteria dalam penelitian yaitu umur, status gizi dan pendidikan menggunakan skala pengukuran ordinal. Teknik pengumpulan data menggunakan teknik dokumentasi. Dimana teknik pengumpulan data yang dilakukan dengan mengadakan pencatatan atau pengutipan dari dokumen yang ada dilokasi penelitian. Penelitian ini juga untuk memperoleh data sekunder dari buku status pasien. Sedangkan dalam analisa data ada dua yaitu Analisa Univariat dan bivariat, dimana analisa univariat yaitu Data yang telah terkumpul akan di analisis secara deskriptif mengenai distribusi frekuensi baik variabel dependen maupun independen, guna mendapatkan gambaran dari masing - masing variabel. Sedangkan Analisa Bivariat yaitu Analisis ini digunakan untuk mencari atau melihat hubungan antara dua variabel. Dalam penelitian ini yaitu menguji hipotesis antara faktor-faktor yang mempengaruhi penyembuhan luka perineum menggunakan uji statistik. Variabel bebas dan variabel terikat berskala ordinal. Oleh karena itu, dalam analisis ini uji statistik yang di gunakan adalah ujiChi-Squaredan uji Fisher's Exact Test.

\section{Pengolahan Data}

a. Editing

Kegiatan ini dilakukan dengan cara memeriksa data hasil jawaban dari lembar checklist yang telah diberikan kepada responden dan kemudian dilakukan koreksi apakah telah terjawab dengan lengkap. Editing dilakukan di lapangan sehingga bila terjadi kekurangan atau tidak sesuai bisa segera dilengkapi.

b. Coding

Kegiatan ini memberi kode angka kepada lembar checklist terhadap tahap-tahap dari jawaban responden agar lebih mudah dalam pengolahan data selanjutnya.

c. Entry data

Kegiatan ini memasukkan data dalam program komputer untuk dilakukan analisis lanjutan.

d. Tabulating

Kegiatan ini dilakukan dengan cara menghitung data dari jawaban lembar checklist responden yang sudah diberi kode, kemudian dimasukkan ke dalam tabel.

\section{Hasil}

Berdasarkan hasil penelitian yang telah dilakukan pada bulan Oktober 2017 dengan jumlah sampel 36 responden. Pengumpulan data dilakukan dengan cara membagikan kuesioner yang berisi pertanyaan tentang faktor - faktor yang mempengaruh lamanya penyembuhan luka perineum pada ibu nifas di ruang perawatan Rumah Sakit Mitra Manakarra Mamuju.

1. Analisa Univariat

a. Lamanya penyembuhan luka perineum

Tabel 1. Distribusi frekuensi kejadian lamanya penyembuhan luka perineum di ruang perawatan rumah sakit mitra manakarra mamuju

\begin{tabular}{ccc}
\hline Kejadian Lamanya Penyembuhan Luka Perineum & n & \% \\
\hline$\leq 7$ Hari & 20 & 55,6 \\
$>7$ Hari & 16 & 44,4 \\
\hline Jumlah & 36 & 100 \\
\hline
\end{tabular}


Tabel 1. Menunjukkan bahwa distribusi frekuensi responden menurut terjadinya lamanya penyembuhan luka perineum, yang $\leq 7$ hari sebanyak $20(55,6 \%)$ responden, sedangkan yang $>7$ hari sebanyak $16(44,4 \%)$ responden.

b. Umur

Tabel 2. Distribusi frekuensi umur tentang lamanya penyembuhan luka perineum di ruang perawatan rumah sakit mitra manakarra mamuju

\begin{tabular}{ccc}
\hline Umur & $\mathbf{n}$ & $\mathbf{\%}$ \\
\hline Beresiko & 14 & 38,9 \\
Tidak Beresiko & 22 & 61,1 \\
\hline Jumlah & 36 & 100 \\
\hline
\end{tabular}

Tabel 2.menunjukkanbahwa distribusi frekuensi responden menurut umur, yang beresiko sebanyak $14(38,9 \%)$ responden, sedangkan yang tidak beresiko sebanyak $22(61,1 \%)$ responden.

c. Status Gizi

Tabel 3. Distribusi frekuensi status gizi di ruang perawatan rumah sakit mitra manakarra mamuju.

\begin{tabular}{ccc}
\hline Status Gizi & n & \% \\
\hline Baik & 18 & 50,0 \\
Kurang & 18 & 50,0 \\
\hline Jumlah & 36 & 100 \\
\hline
\end{tabular}

Tabel 3.menunjukkanbahwa distribusi frekuensi responden menurut status gizi, yang baik sebanyak $18(50,0 \%)$ responden, sedangkan yang kurang sebanyak $18(50,0 \%)$ responden.

d. Pendidikan

Tabel 4. Distribusi frekuensi pendidikan tentang luka perineum di ruang perwatan rumah sakit mitra manakarra mamuju.

\begin{tabular}{ccc}
\hline Pendidikan & n & \% \\
\hline Pendidikan Tinggi & 22 & 61,1 \\
Pendidikan Rendah & 14 & 38,9 \\
\hline Jumlah & 36 & 100
\end{tabular}

Tabel 4.menunjukkanbahwa distribusi frekuensi responden menurut pendidikan, yang pendidikan tinggi sebanyak $22(61,1 \%)$ responden, sedangkan yang pendidikan rendah sebanyak $14(38,9 \%)$ responden.

2. Analisis Bivariat

a. Hubungan umur dengan lamanya penyembuhan luka perineum

Tabel 5. Hubungan umur dengan lamanya penyembuhan luka perineum di ruang perawatan rumah sakit mitra manakarra mamuju

\begin{tabular}{|c|c|c|c|c|c|c|c|}
\hline \multirow{3}{*}{ Umur } & \multicolumn{4}{|c|}{$\begin{array}{c}\text { Kejadian Lamanya } \\
\text { Penyembuhan Luka Perineum }\end{array}$} & \multirow{2}{*}{\multicolumn{2}{|c|}{ Jumlah }} & \multirow[t]{2}{*}{ pvalue } \\
\hline & \multicolumn{2}{|c|}{$\leq 7$ Hari } & \multicolumn{2}{|c|}{ > 7 Hari } & & & \\
\hline & $\mathbf{n}$ & $\%$ & $\mathbf{n}$ & $\%$ & $\mathbf{n}$ & $\%$ & \\
\hline Beresiko & 8 & 22 & 6 & 17 & 14 & 39 & $\rho=0.878$ \\
\hline Tidak Beresiko & 12 & 33 & 10 & 28 & 22 & 61 & \\
\hline Jumlah & 20 & 55 & 16 & 45 & 36 & 100 & \\
\hline
\end{tabular}

Berdasarkan tabel diatas menunjukkan bahwa dari 14 (39\%) responden umur beresiko, yang mengalami penyembuhan luka perineum selama $\leq 7$ hari sebanyak $8(22 \%)$ responden dan yang mengalami penyembuhan luka perineum > 7 hari sebanyak $6(17 \%)$ responden. Sedangkan dari 22 (61\%) responden yang umur tidak beresiko, yang mengalami penyembuhan luka perineum $\leq 7$ hari 
sebanyak $12(33 \%)$ responden, dan yang mengalami penyembuhan luka perineum $>7$ hari sebanyak 10 (28\%) responden.

Hasil uji analisis chi square diperoleh $\rho_{\text {value }}$ lebih besar dari nilai a $(0,878>0,05)$ yang berarti Ho diterima dan Ha ditolak yaitu tidak terdapat hubungan antara usia dengan lama penyembuhan luka perineum.

b. Hubungan status gizi dengan lamanya penyembuhan luka perineum

Tabel 6. Hubungan status gizi dengan lamanya penyembuhan luka perineum di ruang perawatan rumah sakit mitra manakarra mamuju

\begin{tabular}{|c|c|c|c|c|c|c|c|}
\hline \multirow{3}{*}{ Status Gizi } & \multicolumn{4}{|c|}{$\begin{array}{c}\text { Kejadian Lamanya } \\
\text { Penyembuhan Luka Perineum }\end{array}$} & \multirow{2}{*}{\multicolumn{2}{|c|}{ Jumlah }} & \multirow[t]{2}{*}{ pvalue } \\
\hline & \multicolumn{2}{|c|}{$\leq 7$ Hari } & \multicolumn{2}{|c|}{$>7$ Hari } & & & \\
\hline & $\mathbf{n}$ & $\%$ & $\mathbf{n}$ & $\%$ & $\mathbf{n}$ & $\%$ & \multirow{4}{*}{$\rho=0.018$} \\
\hline Baik & 14 & 39 & 4 & 11 & 18 & 50 & \\
\hline Kurang Baik & 6 & 17 & 12 & 33 & 18 & 50 & \\
\hline Jumlah & 20 & 56 & 16 & 44 & 36 & 100 & \\
\hline
\end{tabular}

Berdasarkan tabel diatas menunjukkan bahwa dari $18(50 \%)$ responden yang memiliki status gizi baik, yang mengalami penyembuhan luka perineum selama $\leq 7$ hari sebanyak 14 (39\%) responden dan yang mengalami penyembuhan luka perineum $>7$ hari sebanyak $4(11 \%)$ responden. Sedangkan dari $18(50 \%)$ responden yang memiliki status gizi kurang, yang mengalami penyembuhan luka perineum $\leq$ 7 hari sebanyak $6(17 \%)$ responden, dan yang mengalami penyembuhan luka perineum $>7$ hari sebanyak $12(33 \%)$ responden.

Hasil uji analisis Fisher's Exact Test diperoleh $\rho_{\text {value }}$ lebih kecil dari nilai a $(0,018<0,05)$ yang berarti Ha diterima dan Ho ditolak yaitu terdapat hubungan antara status gizi dengan lama penyembuhan luka perineum.

c. Hubungan pendidikan dengan lamanya penyembuhan luka perineum

Tabel 7. Hubungan pendidikan dengan lamanya penyembuhan luka perineum di ruang perawatan rumah sakit mitra manakarra mamuju

\begin{tabular}{|c|c|c|c|c|c|c|c|}
\hline \multirow{3}{*}{ Pendidikan } & \multicolumn{4}{|c|}{$\begin{array}{c}\text { Kejadian Lamanya } \\
\text { Penyembuhan Luka Perineum }\end{array}$} & \multirow{2}{*}{\multicolumn{2}{|c|}{ Jumlah }} & \multirow[t]{3}{*}{ pvalue } \\
\hline & \multicolumn{2}{|c|}{$\leq 7$ Hari } & \multicolumn{2}{|c|}{$>7$ Hari } & & & \\
\hline & n & $\%$ & n & $\%$ & $\mathbf{n}$ & $\%$ & \\
\hline $\begin{array}{l}\text { Pendidikan } \\
\text { Tinggi }\end{array}$ & 14 & 39 & 4 & 11 & 18 & 50 & $\rho=0.018$ \\
\hline $\begin{array}{l}\text { Pendidikan } \\
\text { Rendah }\end{array}$ & 6 & 17 & 12 & 33 & 18 & 50 & \\
\hline Jumlah & 20 & 56 & 16 & 44 & 36 & 100 & \\
\hline
\end{tabular}

Berdasarkan tabel diatas menunjukkan bahwa dari $22(61 \%)$ responden yang pendidikannya tinggi mengalami penyembuhan luka perineum selama $\leq 7$ hari sebanyak $14(39 \%)$ responden dan yang mengalami penyembuhan luka perineum selama $>7$ hari sebanyak $8(22 \%)$ responden. Sedangkan dari $14(60 \%)$ responden yang pendidikannya rendah mengalami penyembuhan luka perineum selama $\leq 7$ hari sebanyak $6(17 \%)$ responden, dan yang mengalami penyembuhan luka perineum selama $>7$ hari sebanyak $8(22 \%)$ responden. Hasil uji analisis chi square diperoleh $\rho_{\text {value }}$ lebih besar dari nilai a $(0,221<0,05)$ yang berarti Ho diterima dan Ha ditolak yaitu tidak ada hubungan antara pendidkan dengan lama penyembuhan luka perineum.

\section{Pembahasan}

1. Hubungan Umur Dengan Lamanya Penyembuhan Luka Perineum

Menurut Kozier 2011, umur atau usia Anak dan dewasa penyembuhannya lebih cepat dari pada orang tua. Orang tua lebih sering terkena penyakit kronis, penurunan fungsi hati dapat mengganggu sintesis dari faktor pembekuan darah sehingga usia termaksud dalam faktor yang mempengaruhi penyembuhan luka. Namun teori ini bertolak belakang dengan hasil penelitian yangtelah dilakukan, dimana tidak terdapat 
hubungan yang signifikan antara umur dengan lamanya penyembuhan luka perineum. Hal tersebut dapat terjadi karena adanya faktor lain yang menyebabkan usia tidak beresiko mengalami penyembuhan luka diatas 7 hari, seperti personal hygiene. Jika personal hygiene dilakukan dengan baik dan nutrisi tidak terjaga, penyembuhan luka tidak akan cepat sembuh sebagaimana mestinya.

2. Hubungan Status Gizi Dengan Lamanya Penyembuhan Luka Perineum

Terdapat hubungan antara status gizi dengan lama penyembuhan luka perineum. Penelitian ini sejalan dengan hasil penelitian yang di lakukan oleh Yulia Handayani dan Adri Idiana Di Rumah Sakit Umum Dr. Zainoel Abidin Banda Aceh tahun 2014 menyatakan ada hubungan antara faktor nutrisi dengan lama penyembuhan luka perineum.

Dari hasil wawancara yang peneliti lakukan, pada ibu yang status gizinya baik mengatakan bahwa ibu rajin makan makanan yang tinggi protein baik selama hamil sampai masa nifas.Bidan selalu menganjurkan ibu untuk makan makanan yang berprotein tinggi seperti ikan gabus, karena makanan tinggi protein dapat meregenerasi luka dengan cepat.

Pada penelitian ini sebagian besar ibu nifas memiliki gizi yang baik dikarenakan asupan gizi selama ibu di rumah sakit sudah sesuai untuk ibu nifas, namun terdapat masalah yang timbul yaitu ada juga ibu yang memiliki gizi kurang, dikarenakan ibu berpendapat bila ibu menyusui harus banyak makan dan itu akan mengakibatkan ibu menjadi gemuk dan ada juga yang mengalami penurunan nafsu makan setelah melahirkan, hal tersebut yang mengakibatkan IMT ibu menjadi abnormal.

Kebutuhan kalori dan protein pasien hampir pasti menjadi lebih tinggi pada orang normal ketika terdapat luka yang besar.Asam amino diperlukan untuk sintesis protein struktural seperti kolagen dan untuk melakukan sintesa protein yang berperan didalam respon imun (Kozier, 2011).

Sedangkan pada pasien yang status gizinya kurang, lama penyembuhan lukanya diatas tujuh hari mungkin dikarenakan nutrisi yang diperlukan ibu masih dalam proses yang memerlukan waktu untuk memperbaiki status nutrisi mereka setelah melahirkan, sehingga imun yang bekerja untuk penyembuhan luka baru saja akan bekerja, sehingga lama pemyembuhan lukanya diatas tujuh hari. Maka dari itu, diperlukan adanya kesadaran bagi ibu-ibu hamil untuk selalu memeriksakan kehamilannya ditenaga kesehatan untuk mengetahui apakah gizi ibu kurang atau tidak melalui pengukuran LILA dan pentingnya untuk selalu menjaga personal hygiene untuk mencegah infeksi pada luka perineum yang lama penyembuhannya diatas 7 hari.

3. Hubungan Pendidikan Dengan Lamanya Penyembuhan Luka Perineum

Tidak ada hubungan antara pendidikan dengan lama penyembuhan luka perineum.Penelitian ini tidak sejalan dengan penelitian yang telah dilakukan oleh Susi Rahmawati (2012) tentang faktor-faktor yang berhubungan dengan perawatan luka perineum pada ibu nifas di Rumah Sakit Umum Cempaka, menunjukkan bahwa responden yang memiliki pengetahuan baik akan berdampak baik pula terhadap penyembuhan luka perineum. Hasil penelitian ini juga berbeda dengan teori yang diungkapkan oleh Notoatmodjo, 2013. Dimana menurutnya Tingkat pendidikan mempunyai hubungan yang eksponensial dengan tingkat kesehatan semakin tinggi tingkat pendidikan semakin mudah menerima informasi yang diterima.Konsep hidup sehat secara mandiri, kreatif dan berkesinambungan.Latar belakang pendidikan seorang ibu sangat berpengaruh terhadap tingkat pengetahuan ibu. Semakin tinggi pendidikan maka semakin mudah ibu mendapatkan informasi. Keterbatasan dalam penelitian ini juga karena keterbatasan waktu dan pemahaman peneliti sehingga diharapkan ada peneliti lain yang melakukan penelitian dengan kasus yang sama.

\section{Kesimpulan}

Tidak ada hubungan yang signifikan antara umur dan pendidikan dengan kejadian lamanya penyembuhan luka perineum, namun pada hasil uji status gizi terdapat hubungan yang signifikan dengan kejadian lamanya penyembuhan luka perineum.

Disarankan pada peneliti selanjutnya dengan masalah yang sama dan menambahkan variabel bebas yang lain agar lebih memperdalam hasil dan pembahasan sehingga lebih bermanfaat dalam perkembangan ilmu pengetahuan.

Peneliti mengucapkan banyak terima kasih kepada pihak-pihak yang telah berkontribusi dalam proses penelitian ini, terutama kepada Pihak rumah sakit mitra manakarra, responden dan keluarga, serta teman-teman sejawat yang membantu dalam proses penelitian ini.

\section{Saran}

1. Bagi Institusi Pendidikan

Diharapkan bagi institusi mempertimbangkan untuk mengadakan penyuluhan atau sosialisasi di masyarakat tentang faktor-faktor yang mempengaruhi lamanya penyembuhan luka perineum pada ibu nifas. 
2. Bagi Tempat Penelitian

Meningkatkan dalam pemberian pelayanan yang terbaik bagi pasien sesuai dengan prosedur yang telah ditetapkan agar dapat mempercepat penyembuhan luka perineum.

3. Bagi Peneliti

Lebih meningkatkan membaca buku - buku, artikel, jurnal, dan majalah majalah tentang hal-hal yang berhubungan dengan luka perineum pada ibu nifas.

\section{Referensi}

Almatsier, Sunita. 2011. Prinsip Dasar Ilmu Gizi. Jakarta : PT. Gramedia Pustaka Utama.

Ambarwati\& Wulandari.2012. Asuhan Kebidanan Nifas Normal.Jakarta : EGC.

Anggraeni. 2012. Asuhan Kebidanan Masa Nifas. Yogyakarta : Pustaka Rihana.

APN. 2007. Pedoman Pelayanan Antenatal. Jakarta : direktorat Bina Pelayanan Medik Dasar.

Arikunto. 2012. Prosedur Penelitian Suatu Pendekatan Praktis. Jakarta:Rineka Cipta.

Bobak. 2010. Buku Ajar Keperawatan Maternitas. Jakarta: EGC.

Boyle, M. 2008. Pemulihan Luka. Jakarta : EGC.

Buku Register Ruang Kebidanan BLUD Rumah Sakit Kabupaten Konawe. 2017.

Darmawati \& la Sastra.2012. Hubungan Faktor-Faktor Yang Mempengaruhi Penyembuhan Luka Dengan Lama Penyembuhan Luka Perineum Ibu Nifas. Idea Nursing jurnal, ISSN : 2087-2879

Depkes, RI. 2013. Profil Kesehatan Indonesia. Jakarta.

Chrisvalen. 2012. Tingkat Pengetahuan Ibu Tentang Infeksi Luka Perineum di RSU Assalam Gemorong Sragen. Karya Tulis Ilmiah DIII Kebidanan STIKES Kusuma Husada : Surakarta.

Handayani Yulia. 2014. Faktor-Faktor Yang Mempengaruhi Penyembuhan Luka Perineum Pada Ibu Nifas Di Rumah Sakit Umum Dr. Zainoel Abidin Banda Aceh. Karya Tulis Ilmiah Progran Stidy D-IV Kebidanan, STIKES Budiyah Banda Aceh.

Herdiansyah. 2012. Metodologi Penelitian Kualitatif Untuk Ilmu-ilmu Sosial. Jakarta : Salemba Medika.

Hidayat, Alimul. 2011. Metode Penelitian Kebidanan Dan Teknik Analisa Data.Jakarta : Salemba Medika.

Hilmy. 2010. Rupture Perineum. http://scribd.com diakses pada Juni 2017

Kamus Besar Bahsa Indonesia. 2017.

Kemenkes, RI. 2016. Profil Kesehatan Indonesia. Jakarta.

Kozier, dkk. 2011. Buku Ajar Fundamental Keperawatan (ed.7 Vol. 2). Jakarta : EGC.

Manuaba. 2011. Ilmu Kebidanan, Penyakit Kandungan Dan Keluarga Berencana Untuk Pendidikan Bidan. Jakarta : EGC.

Manuaba, dkk. 2011. Pengantar Kuliah Obstetri. Jakarta : EGC.

Notoatmodjo. 2013. Metodologi Penelitian Kesehatan. Jakarta : Rineka Cipta.

Nugraheni, E. 2012. Asuhan Kebidanan Patologi. Yogyakarta : Pustaka Rihana. 
Oxorn , Harry, Et Al. 2010. Ilmu Kebidanan Patologi \& Fisiologi Persalinan.Yogyakarta :Yayasan Esensial Medika.

Prawirohardjo, S. 2012. Ilmu Kebidanan. Jakarta : Yayasan Bina Pustaka Sarwono Prawirohardjo.

Proverawati, A. 2010. BBLR (Berat Badan Lahir Rendah). Yogyakarta : Nuha Medika.

Rukiyah, dkk. 2012. Asuhan Kebidanan III (Nifas). Jakarta : Salemba Medika.

Saifuddin. 2013. Panduan Praktis Pelayanan Kesehatan Maternal dan Neonatal. Jakarta : Yayasan Bina Pustaka Sarwono Prawirohardjo.

Sugiyono. 2015. Statistik Untuk Penelitian. Yogyakarta : Alfabeta Bandung.

Suherni, dkk. 2013. Perawatan Masa Nifas. Yogyakarta : Fitramaya.

Sukisno Anita R. 2014. Lama Penyembuhan Luka Perineum Pada Ibu Post Partum Yang Melakukan Senam Nifas Di Polindes Ngembeh Dlanggu Kabupaten Mojokerto. Laporan Penelitian.

Sulistyawati, A. 2012. Asuhan Kebidanan Pada Masa Kehamilan. Jakarta : Salemba Medika.

Supariasa. 2013. Pendidikan Dan Konsultasi Gizi. Jakarta : EGC

Thompson. 2009. Kehamilan Dari Pembuahan Hingga Kelahiran. Jakarta : Dian Rakyat.

Taylor C. Et Al. 2009. Fundamental of Nursing the Art Science of Nursing Care B. Third edition.Philadhelpia : Lippincott.

Wiknjosastro, dkk. 2012. Ilmu Kebidanan. Jakarta : Yayasan Bina Pustaka Sarwono Prawirohardjo. 